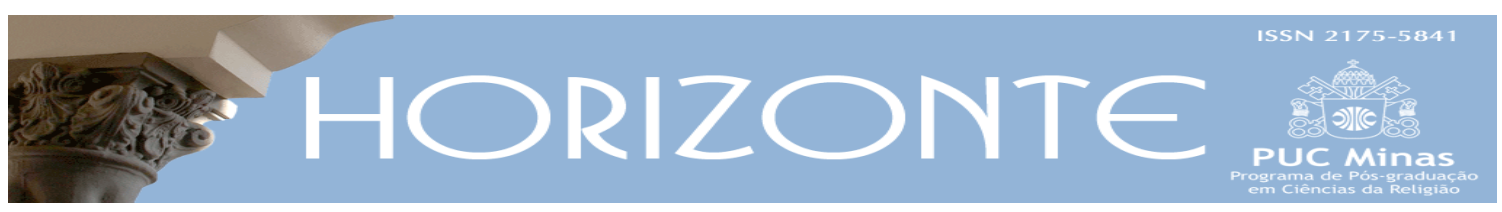

Temática Livre - Artigo Original

DOI - 10.5752/P.2175-5841.2020v18n56p648

\title{
Transversalidades entre conservadorismo e progressismo católicos: \\ Geraldo de Proença Sigaud, Helder Pessoa Camara e o Concílio Vaticano II
}

\author{
Transversalities between catholic conservatism and progressiveness: \\ Geraldo de Proença Sigaud, Helder Pessoa Camara and the \\ Second Vatican Council
}

\author{
Newton Darwin de Andrade Cabral* \\ Rodrigo Coppe Caldeira**
}

\begin{abstract}
Resumo
Uma assembleia com as dimensões do Concílio Vaticano II necessariamente aglutinaria diversificadas correntes e perspectivas. No episcopado brasileiro a heterogeneidade também foi uma marca. Considerando tais dados, este artigo foi escrito com dois objetivos maiores: identificar transversalidades nas formas de pensar e agir de Proença Sigaud e Helder Camara, a partir dos temas propostos para o Concílio e analisar afinidades/convergências e oposições/divergências existentes entre as suas posições, respectivamente conservadoras e progressistas, sobretudo a partir das respostas (vota) que elaboraram às consultas solicitadas na fase antepreparatória; perpassando o trabalho, há discussões remetendo aos grupos a que se associaram e às articulações estabelecidas, bem como aos seus epistolários e questões neles tratadas. Baseado em pesquisas bibliográfica e documental - realizada, esta, nos arquivos do Instituto Dom Helder Camara e da Cúria Arquidiocesana de Diamantina - com o artigo foi possível reforçar o entendimento de que a diversidade de perspectivas doutrinais e pastorais é fato inconteste, ainda que salvaguardada a unidade; outrossim, a transversalidade evidenciou, a partir da abordagem de temas sociopolíticos e religiosos, a existência de preocupações semelhantes que implicavam, nas posições majoritariamente antagônicas dos dois, igual empenho pela adoção de medidas, ainda que habitualmente díspares, no tocante à forma de analisá-los e enfrentá-los.
\end{abstract}

Palavras-chave: Igreja Católica. Modelos eclesiais. Poder. Pensamento helderiano. Pensamento sigaudiano.

\begin{abstract}
An assembly with the dimensions of the Second Vatican Council necessarily would agglutinate diversified chains and perspectives. In Brazilian's episcopy the heterogeneity was also a mark. Given this data, this article was written with two big goals: identify transversalities on the forms of thinking and acting of Proença Sigaud and Helder Camara, from the big themes proposed for the Second Vatican Council, and analyze affinities/convergences and oppositions/divergences existent between the positions, respectively progressives and conservatives, especially since the answers (vota) that were elaborated to the solicited consultations at the ante preparatory phase; related to the work, there are discussions referring to the groups which they associated themselves with and the articulations established, as well as theirs epistolates and the questions on them treated. Based on bibliographic and documental researches - realized, this, on Institute Helder Camara's archive and at Diamantina's Archdiocesan Curia - with the article it was possible to reinforce the understanding that the diversity of doctrinal and pastorals perspectives is uncontested fact, even if safeguarded the unity; besides that, the transversality highlighted, from the approach of determined socio political and religious themes, the existence of similar preoccupations that implied, at mostly antagonistics positions from the two, equal effort for the adoption of measures, even though habitually disparate, concerning the way of analyzing and dealing with them.
\end{abstract}

Keywords: Catholic Church. Ecclesial models. Power. Helder's thoughts. Sigaud's thoughts.

Artigo submetido em 27 de maio de 2020 e aprovado em 19 de agosto de 2020.

* Doutor em História pela UFPE. Professor da UNICAP. País de origem: Brasil. E-mail: newton.cabral@unicap.br

** Doutor em Ciência da Religião pela UFJF. Professor da PUC Minas. País de origem: Brasil. E-mail: rodrigocoppe@gmail.com 


\title{
Introdução
}

Realizado entre 1962 e 1965 - e por muitos considerado o mais importante evento eclesial de todo o século XX - o Concílio Ecumênico do Vaticano II possibilitou que o catolicismo se reconciliasse com as ideias de liberdade religiosa, diálogo ecumênico e justiça social, embora ainda o tenha feito, notadamente, a partir de uma ótica europeia.

O seu anúncio (25 de janeiro de 1959), suscitou diversas expectativas:

\begin{abstract}
Alguns viram nele a promessa de uma renovação esperada há tanto tempo, outros valorizaram a possibilidade de colocar no primeiro plano o problema da unidade dos cristãos, e outros sublinharam a possibilidade de uma relação da Igreja com a sociedade em termos de fraternidade e não mais de contraposição. (ALBERIGO, 1995, p. 396).
\end{abstract}

Longamente preparada, aquela assembleia não podia aglutinar, em linhas de ação similares, as múltiplas tendências existentes na Igreja; aliás, isso não era possível sequer na Conferência Nacional dos Bispos do Brasil (CNBB), na qual o quantitativo de prelados necessariamente conduzia à diversidade de posições.

Ainda que os vocábulos progressismo e conservadorismo comportem polissemias, neste artigo eles são utilizados, sobretudo, a partir de concepções acerca do poder na Igreja, tanto internamente, quanto em suas relações com outras instituições sociais. Em tal diapasão, os casos dos bispos e das posições progressistas são mais conhecidos e estudados. Situação proporcional não é registrada com relação à linha conservadora, sendo ainda quase inexistentes as pesquisas sistemáticas que estabelecem paralelos entre elas.

No Concílio Vaticano II, dois (arce)bispos católicos brasileiros - Geraldo de Proença Sigaud (Jacarezinho/PR, 1947-1961 e Diamantina/MG, 1961-1980) e Helder Pessoa Camara (Rio de Janeiro/RJ, 1952-1964 e Olinda e Recife/PE, 1964-1985) -, ambos participantes das quatro sessões conciliares, destacaramse por representarem, respectivamente, inclusive na condição de seus baluartes, as posições conservadora e progressista. 
O artigo tem como objetivo central analisar a compreensão eclesiológica de ambos no imediato momento pré-conciliar. Para tanto, foi utilizada a perspectiva da transversalidade, realizada via mergulho analítico na documentação existente e garimpada sobretudo através dos votos emitidos nas consultas preparatórias; todavia, não deixaram de ser levadas em consideração as articulações que eles estabeleceram, em Roma, nos períodos conciliares, bem como correspondências que mantiveram com amigos, assessores, aliados etc., ainda que os dois últimos aspectos não tenham recebido, aqui, a ênfase que demos aos vota.

Ainda que óbvio, não deixamos de fazer o destaque de que em algumas das fontes utilizadas na pesquisa, foram constatadas diferenças acentuadas, pois, se ao contrário de Proença Sigaud, Helder Camara não fez pronunciamentos nas Aulas Conciliares, em muito este superou o montante de cartas escritas por aquele, havendo também nítida discrepância entre o número de livros publicados por eles e sobre suas trajetórias.

Consideramos importante destacar, com relação às fontes, não ter sido publicada, até o momento, uma tradução para o português da íntegra dos consilia et vota redigidos em latim ou em outras línguas.

\section{Consilia et vota: o horizonte de expectativa dos bispos}

Podemos dizer que os vota são fontes centrais para o estudo do Vaticano II pelo fato de que eles oferecem elementos do imaginário, as representações e o horizonte de expectativa que os bispos exalavam no período imediatamente anterior ao início do evento conciliar.

Como diz Reis ao analisar a obra de Reinhart Koselleck, "a história é sempre a de experiências vividas e de esperas dos homens que agem e sofrem." (REIS, 1994, p. 82). Os vota oferecem, assim, uma janela pela qual podemos acessar como aqueles prelados que os produziram entendiam seu tempo e o que esperavam do futuro concílio.

A partir do estudo destas fontes recriamos, mesmo que de maneira sempre não exaustiva, o espaço mental pelo qual se moveram e se constituíram 
como sujeitos históricos os bispos Proença Sigaud e Helder Camara, personagens que desempenharam papéis de destaque na assembleia, transitando em intrincadas redes de sociabilidade que visavam a influenciar o concílio. Como ensina propriamente Koselleck: "o tempo histórico, caso o conceito tenha mesmo um sentido próprio, está associado à ação social e política, a homens concretos que agem e sofrem as consequências de ações”. (KOSELLECK, 2006, p. 14).

Eis o que buscamos compreender a partir dessa aproximação dos vota de Proença Sigaud e Helder Camara: como ambos teceram suas imagens de Igreja no tempo em que viveram e o que esperavam do novo concílio, buscando compará-los a partir de uma análise transversal.

$\mathrm{Na}$ fase antepreparatória (1959-1960) do concílio foi enviada pelo Secretário de Estado do Vaticano - Cardeal Domenico Tardini - uma consulta a todos os bispos, visando a estabelecer as questões principais para a elaboração da agenda da assembleia conciliar. Essa consulta, entretanto, sofreu alterações, uma vez que foi pensada, inicialmente, como um questionário cujas opções implicariam um resultado restrito. Não sem resistências da Cúria Romana, adotou-se, posteriormente, uma carta aberta que deixava os consultados com mais liberdade para enviar até Roma suas sugestões acerca do que julgavam ser as temáticas prioritárias. (BEOZZO, 2005). São elas que nos possibilitam entrever as imagens eclesiais construídas pelos bispos em questão.

Datada em 18 de junho de 1959, a carta diz querer concretizar o desejo do Papa João XXIII de "conhecer opiniões e pareceres e recolher conselhos e vota" (BEOZZO, 2005, p. 78), dos que são chamados, de acordo com as determinações do Direito Canônico, a participar do Concílio Ecumênico:

Peço, portanto, vivamente a V.Ex.cia que queira fazer chegar a esta Comissão Pontifícia, com absoluta liberdade e sinceridade, pareceres, conselhos e vota que a solicitude pastoral e o zelo das almas possam sugerir a V.Ex.cia em ordem às matérias e aos temas que poderão ser discutidos no próximo Concílio. Esses temas poderão dizer respeito a alguns pontos de doutrina, disciplina do clero e do povo cristão, a múltipla atividade que empenha toda a Igreja, os problemas de maior importância que essa deve enfrentar hoje, e toda outra coisa que V.Ex.cia julgar oportuno apresentar e desenvolver. (BEOZZO, 2005, p. 78, grifo nosso). 
Do Brasil responderam pouco mais de 130 bispos e/ou prelados nullius, de um total de 167 que estavam aptos a fazê-loํㅜ ${ }^{1}$ o que correspondeu a $78 \%$. Suas "respostas ocupam 216 páginas do volume II, Pars VII, dos Acta et Documenta, indo da página 127 a 343 do tomo indicado”. (BEOZZO, 2005, p. 86).

Luiz Baraúna, que foi perito conciliar, publicou estudo acerca das respostas do episcopado do país. Nele, estabeleceu uma tipologia que divide o conjunto dos brasileiros a partir de três posturas: uma minoria ultrarreacionária, uma minoria precursora e profética e uma grande maioria conservadora ou moderada. Nos dois primeiros grupos inclui, respectivamente, Proença Sigaud e Helder Camara (BARAÚNA, 1993, p. 146-177)²; porém, não se detém aos vota de cada um, o que faremos em seguida.

Beozzo (1993) apresenta a relação completa dos que receberam a consulta, e lista as páginas em que estão cada resposta enviada, no volume supracitado das Acta et Documenta. Em uma análise inicialmente quantitativa, levamos em consideração a citação da(s) página(s), sem nos preocuparmos em verificar, com precisão, se todas as citadas foram preenchidas em parte ou em sua totalidade. O votum de Helder Camara, por exemplo, está publicado nas páginas 325 a 327; apesar de Baraúna (1993) explicitar que ela ocupa duas páginas e meia - o que visualizamos no original -, neste artigo consideramos três; igual procedimento adotamos para com todos os demais.

Para estabelecermos parâmetros comparativos, partimos de figuras que ocupavam posições de destaque no episcopado do Brasil e percebemos que as respostas dos três cardeais - Augusto Álvaro da Silva (São Salvador da Bahia), Carlos Carmelo de Vasconcelos Motta (São Paulo) e Jaime de Barros Câmara (São Sebastião do Rio de Janeiro) - ocuparam, respectivamente, 2, 4 e 5 páginas. Também foi de 5 páginas, a resposta do Núncio Apostólico (Dom Armando Lombardi), o que nos instigou a buscarmos identificar quantos e quais

\footnotetext{
${ }^{1}$ No total, eram 2.593 os destinatários, dos quais responderam 1.998 (ALBERIGO, 1995, p. 396), totalizando 77\%.

${ }^{2}$ No final da década de 1950, Mainwaring afirma que podemos encontrar três grupos principais dentro da Igreja: "aqueles que continuavam a endossar a estratégia da neocristandade passaram a ser os tradicionalistas, [...] os modernizadores conservadores acreditavam que a Igreja precisava mudar para cumprir sua missão no mundo moderno [...] se preocupavam com a secularização, com a expansão do protestantismo, com a ameaça comunista, mas respondiam com maior abertura ao mundo, [...] reformistas [...] compartilhavam a preocupação dos modernizadores conservadores com o trabalho pastoral mais intenso e uma educação religiosa mais eficaz, mas suas posições sociais eram mais progressistas [...] se preocupavam mais com a mudança social como um fim em si". (MAINWARING, 1989, p. 56-57).
} 
bispos e prelados nullius ultrapassaram 5 páginas. Assim, constatamos que apenas seis foram além: três usaram 6 páginas ${ }^{3}$, um escreveu em 8 páginas 4 , outro estendeu-se por 13 páginas 5 e um terceiro foi o recordista: o então bispo de Jacarezinho (PR), Geraldo de Proença Sigaud, cujo votum ocupou 16 páginas: da 180 a 195. (BEOZZO, 2005). Salientamos que a carta do Cardeal Tardini nada orientava sobre o tamanho das respostas. Trazia como única recomendação serem redigidas em latim ${ }^{6}$ e solicitava que fossem enviadas, preferencialmente, antes de 12 de setembro daquele ano de 1959.

\section{Votum de Geraldo de Proença Sigaud}

Por quatro vezes, Proença Sigaud faz referências - no início e na finalização de sua contribuição - às suas "modéstia e humildade"; chegou a autodefinir-se como "um obscuro bispo que enviava despretensiosas anotações" (VOTOS e documentos preparatórios para o Concílio Vaticano II, 1961, p. 180). Não obstante a sua alegação de que eram despretensiosas anotações, ressaltamos não ser o que se verifica, pelo menos em termos de volume, pois, entre os bispos brasileiros que responderam à consulta, foi quem mais escreveu, conforme supradestacado.

Dois vocábulos, seguidos de expressões que lhes são correlatas, chamam a atenção na leitura do votum de Proença Sigaud: revolução é uma palavra citada 22 vezes e, comunismo, em 21 ocasiões. Acompanham o vocábulo revolução, locuções como "ciência da revolução", "conspiração revolucionária", "comunidade revolucionária", "sociedade revolucionária", "propaganda revolucionária", "campanha contrarrevolucionária", "luta contrarrevolucionária”, "guerra contrarrevolucionária” e "ação contrarrevolucionária”. Por sua vez, fazem parte do grupo afim ao vocábulo

\footnotetext{
${ }^{3}$ Antônio Barbosa (de Campo Grande - MS), Carlos Eduardo de Saboia Bandeira de Mello (de Palmas - PR) e Walmor Battu Wichrowski (de Santos - SP).

${ }^{4}$ Antônio de Castro Mayer (de Campos - RJ), aliado de Proença Sigaud na maioria das pautas sociopolíticas e religiosas. Foram, ambos, apoiadores da TFP (Sociedade Brasileira de Defesa da Tradição, Família e Propriedade).

${ }^{5}$ Afonso Maria Ungarelli (Pinheiro - MA).

${ }^{6}$ Tanto Proença Sigaud quanto Helder Camara redigiram seus vota em latim, como o fez a maioria dos bispos e prelados nullius. Houve, porém, casos de vários que o fizeram em suas línguas maternas - quando estrangeiros atuantes no Brasil -, e de alguns que optaram pela língua portuguesa.
} 
comunismo, as expressões "socialismo", "utopia socialista" e "sociedade socialista” 7 .

Não pairam dúvidas acerca de a que estaria se referindo o bispo de Jacarezinho quando focava o tema comunismo, haja vista ser do conhecimento de todos os que parcialmente conhecem o pensamento de Proença Sigaud o quanto a luta contra o que ele chamava de seita foi uma constante em sua atuação - sem que isso significasse caso único entre os bispos ou uma idiossincrasia do então titular daquela diocese paranaense. Aliás, aos 6 de janeiro de 1962, ele escreveu uma carta pastoral sobre o tema ${ }^{8}$, além de ter, posteriormente, publicado o Catecismo anticomunista que foi traduzido para aproximadamente uma dezena de idiomas 9.

Quanto ao significado de revolução, diz Proença Sigaud:

O inimigo implacável da nossa Igreja e da Comunidade Católica, há seis séculos, em uma progressão lenta e sistemática, quase abalou e destruiu o ordenamento católico. Isto é, a Cidade de Deus, e se tem esforçado para, no seu lugar, edificar a Cidade do Homem, cujo nome é Revolução, [que deseja] construir sem Deus todo o ordenamento da vida humana, bem como uma Humanidade e uma Sociedade sem Cristo, sem Revelação, sem Igreja, estruturada e fundamentada somente na Razão Humana, na Sensualidade, na Ganância e na Soberba. (VOTOS e documentos preparatórios para o Concílio Vaticano II, 1961, p. 182).

Para o Bispo de Jacarezinho, o espírito da Revolução já havia penetrado nos fiéis católicos e no clero, a ponto de serem perseguidos os que, neste, se insurgiam contra os seus erros e os denunciavam, chegando a ser as posições por eles assumidas um critério de escolha para o episcopado, preferindo-se os que a apoiavam. Para o epíscopo, tal realidade implicava a necessidade de a Igreja, em todo o mundo, organizar-se para lutar sistematicamente contra a revolução, que era conduzida pelas forças das seguintes organizações: a Franco-

\footnotetext{
${ }^{7}$ A tradução dos vota para o português foi efetuada pelo latinista José Gaudêncio de Oliveira Lopes, ex-professor da Graduação em Letras, da Universidade Católica de Pernambuco, a quem agradecemos.

${ }^{8}$ Impossibilitado, por questões de saúde, de escrever uma saudação aos fiéis da Arquidiocese de Diamantina logo que tomou posse, em 1961, escolheu este tema para a sua primeira carta pastoral. Nela, retoma - e amplia - alguns conteúdos do seu votum. (SIGAUD, 1963).

9 Lembramos que o opúsculo foi publicado pela editora Vera Cruz, a mesma que publicava textos e livros de membros da Sociedade de Defesa da Tradição, Família e Propriedade (TFP), movimento brasileiro de direita, fundado em 1960, que teve penetração em vários países. Proença Sigaud, junto com Castro Mayer, bispo de Campos dos Goytacazes, que tinham contato com o seu líder, Plínio Corrêa de Oliveira, desde a década de 1930, apoiavam diretamente o movimento. Em 2018 foi publicada uma nova edição do Catecismo anticomunista. Nela, de forma similar à carta pastoral citada, Proença Sigaud retoma conceitos e posições que defendeu em seu votum, aos quais deu, desde a primeira edição, a forma então usada nos catecismos: perguntas e respostas. (SIGAUD, 2018).
} 
maçonaria ${ }^{10}$, o Comunismo e o Judaísmo internacional. ${ }^{11}$ À maçonaria caberia o papel de arrebanhar os burgueses ao passo que o comunismo organizaria o proletariado. Possuidores da idêntica proposta de uma sociedade socialista regida pela razão, sem Deus e sem Cristo - ambos seriam financiados pelo judaísmo, pois os segredos atômicos americanos foram traídos por judeus (Fuchs, Golds, Gringlass, Rosemberg) que, igualmente, são os fundadores, divulgadores e organizadores do comunismo.

Proença Sigaud enumera marcos que, em sua análise, pontuam as mudanças históricas da revolução, cujo início teria acontecido na Idade Média, continuado no Renascimento, avançado acentuadamente com a Reforma Luterana, prosseguido com a Revolução Francesa ${ }^{12}$, chegado ao Modernismo e tivera ápice com o comunismo, cujos mecanismos buscam ser eficazes na erradicação do cristianismo. Assim, a revolução seria detentora de grande força que "advém do eficiente uso das paixões humanas. O Comunismo criou a ciência da Revolução e suas principais armas: as paixões humanas desenfreadas metodicamente incitadas”. (VOTOS e documentos preparatórios para o Concílio Vaticano II, 1961, p. 182-184).13

A revolução emprega dois vícios como forças destruidoras da comunidade católica e, por outro lado, construtoras da sociedade ateia: a Sensualidade e a Soberba. Estas paixões desordenadas e irrefreáveis são orientadas de forma científica para um fim preciso e são forçadas a submeter-se à férrea disciplina de seus chefes na tentativa de destruir por completo a Cidade de Deus, e no seu lugar edificar a Cidade do Homem. (VOTOS e documentos preparatórios para o Concílio Vaticano II, 1961, p. 184).

Após diagnosticar e discorrer sobre o estado da questão (revolução), na continuidade de seu votum, Proença Sigaud sugere princípios que balizem as formas de reação católica contra o inimigo, lembrando que apenas condenar as

\footnotetext{
10 Proença Sigaud chega a afirmar que "brevemente a Maçonaria atingirá toda a humanidade". (VOTOS e documentos preparatórios para o Concílio Vaticano II, 1961, p. 183).

${ }^{11}$ A questão do judaísmo, pedra de toque da intransigência católica, estará presente por todo o concílio. Uma quantidade expressiva de material antissemita circulará entre os padres conciliares. Cita-se como exemplo o livro Complô contra a lgreja, obra de centenas de páginas que defende que os judeus teriam sido os principais inimigos da Igreja católica, atentando contra ela desde o início da história cristã. Defendia que o comunismo era a última tentativa para destruir o catolicismo e a civilização ocidental, e o concílio o seu instrumento (CALDEIRA, 2011).

${ }^{12}$ Em sua visão, os significados do lema da Revolução Francesa - Égalité, Fraternité e Liberté - apontariam para uma sociedade sem rei e sem autoridade (Igualdade), sem propriedade privada e sem classes sociais (Fraternidade) e sem Deus (Liberdade).

${ }^{13}$ Esse trecho do votum de Sigaud deixa claras as ressonâncias do pensamento de Plínio Corrêa de Oliveira, sobre ele. O líder da TFP publicou, em 1959, no O Catolicismo - jornal da Diocese de Campos dos Goytacazes que, na condição de periódico diocesano, tinha apoio do então bispo, Antonio de Castro Mayer - o artigo Revolução e Contra-revolução. Esse texto é fundamental no imaginário tefepista e trazia uma espécie de filosofia da história em que Plínio apresentava os momentos cruciais da Revolução, força secreta por trás dos movimentos que visam a destruição da Igreja.
} 
doutrinas, ainda que alcance bons resultados, não é suficiente. Para ele, faz-se necessária uma resistência organizada que:

1. promova uma ampliação do Syllabus do Papa Pio IX, de maneira que sejam incluídos os erros contemporâneos, como os do Socialismo, de Marc Sangnier, de Sillon e de Jacques Maritain, da Democracia Cristã, do Liturgicismo, do Sacerdócio dos Leigos da Ação Católica, do Comunismo (a respeito da propriedade privada), dos erros sobre a obediência e sobre os votos religiosos ${ }^{14}$;

2. não admita a tática da admissão do "mal menor", a qual conduz ao esquecimento de que todo mal deve ser combatido;

3. crie barreiras para que não haja "conformidade com o espírito do século". Assim, "que todos os fiéis entendam ser irreconciliável a contradição entre a Igreja e o mundo. E se os 'tempos atuais' são mais do mundo pagão do que de Deus, então que os católicos não participem desses 'tempos atuais"';

4. atente para os perigos da colaboração com os não católicos, que podem ser benéficas em questões específicas sobre a fé, mas é impossível em termos de colaboração, em decorrência da diversidade dos princípios, do fim e da essência da doutrina. "Da aproximação com os não católicos eles só têm o que lucrar e os católicos só têm o que perder"15;

5. evite os malefícios do "mito da boa fé", não delegando importantes funções a pessoas cuja fidelidade não tenha sido comprovada. (VOTOS e documentos preparatórios para o Concílio Vaticano II, 1961, p. 185-188).

Na sequência, aponta alguns meios de corrupção, a seu ver então existentes. Dentre eles destaca:

a. as danças (por causa da intimidade corporal que estabelecem entre um homem e uma mulher; no entanto, para ele também as coreografias do "rock-and-roll” e de outras modalidades devem ser evitadas, inclusive o balé, pois este contém “um sensual e exagerado culto do corpo”);

\footnotetext{
${ }^{14}$ Não há explicitações acerca do(s) motivo(s) a partir do(s) qual(is) considera erros alguns dos aspectos citados.

${ }^{15}$ Outra afirmação efetuada sem as devidas justificativas.
} 
b. a moda (o destaque é para o vestuário feminino, que atenta contra a modéstia, devendo os missionários para ela educarem os povos primitivos; exorta para a seminudez das roupas femininas usadas nos banhos de mar ou de piscina, que deve ser evitada);

c. os concursos de beleza (devem ser banidos e excomungados candidatas, juízes, promotores e financiadores de tais eventos que expõem "o corpo da mulher jovem para a admiração do Belo, o que implica exacerbação dos sentidos);

d. o cinema (ainda que haja uma produção voltada à informação e educação, ele prejudica "a religiosidade católica porque dissipa a mente" e “pode enfraquecer a vida espiritual”):

\begin{abstract}
Até o cinema-arte, que por natureza pretende ser amoral, isto é, não ataca nem defende a moral, mas é concebido para a alegria, deleite e reflexão filosófica, participa, em última análise, da mesma natureza das novelas e dos romances. Se por um lado excita a fantasia e as paixões, por outro também aguça a sensibilidade e o espírito de observação. (VOTOS e documentos preparatórios para o Concílio Vaticano II, p. 188-189);
\end{abstract}

e. os livros (após elogiar os êxitos aferidos pelo Index Librorum Prohibitorum elaborado pelo Santo Ofício, lamenta a tardia condenação de autores como André Gide e outra vez cita a necessidade de procedimento idêntico vir a ser adotado para com Jacques Maritain. (VOTOS e documentos preparatórios para o Concílio Vaticano II, 1961, p. 189).

No campo do que denomina dificuldades internas, após lamentar a estagnação dos estudos sobre a Escolástica, evidencia seu desagrado por estarem na liderança do pensamento ocidental autores como Sartre, Freud e Dostoyewsky (sic). Enfatiza a necessidade de o Concílio "fazer surgir uma nova vitalidade para a doutrinação católica” e expande a relação de assuntos/teóricos a serem evitados: socialismo cristão, nominalismo, idealismo kantiano, Hegel, Sartre e o maritainismo; a estes acresce o positivismo jurídico, o maniqueísmo e o gnosticismo - "que se revelam na Arte Abstracionista" -, (VOTOS e documentos preparatórios para o Concílio Vaticano II, 1961, p. 190), além dos teosofismo, Rotary Club, Lyons Club e do Movimento do Rearmamento Moral. Em seguida, todo um parágrafo de críticas é dedicado ao naturalismo 
pedagógico de Rousseau. Teillard de Chardin também foi rechaçado em momento anterior do seu votum.

Para enveredar na discussão sobre a necessária campanha contrarrevolucionária destaca:

A Conspiração Revolucionária é una e bem organizada. Essa mesma conspiração deve ser combatida de forma uniforme e sistemática. Os católicos esperam receber do governo da Igreja um detalhamento concreto e prático, fundamental e bem estruturado da comunidade católica e da campanha contrarrevolucionária, na qual estejam devidamente incluídos, de forma bem disposta, os bons aspectos da vida moderna, justamente aqueles que a sociedade tradicional cultua e deve continuar cultuando. (VOTOS e documentos preparatórios para o Concílio Vaticano II, 1961, p. 191).

A discussão tem continuidade com assertivas sobre a reedificação da comunidade católica, a ser feita com base no poder da Santa Sé que, para tanto, deve convocar os fiéis e instruí-los "de forma enérgica, compreensível e metódica” para a campanha que propõe. Requer também a impugnação do comunismo $^{16}$ - sem repetir a postura claudicante assumida pela Igreja, no século XIX, com relação ao liberalismo - e sem escusar-se de enfatizar a necessidade de o Concílio Ecumênico efetuar "uma solene e severa condenação" da utopia socialista. (VOTOS e documentos preparatórios para o Concílio Vaticano II, 1961, p. 192):

\begin{abstract}
A nossa vida terrena não pode ser paradisíaca. A cruz, a paciência, a abnegação são indispensáveis para se compreender bem a razão maior da nossa passagem por este mundo. A caridade, sobretudo a caridade, é necessária, muito mais do que a justiça.

$\mathrm{Na}$ verdade, jamais acontecerá esse paraíso socialista aqui na terra. Buscando o reino de Deus e sua justiça, o ser humano já vai obtendo aquela dimensão de felicidade que a amorosa e Divina Providência vai concedendo a seus filhos aqui nesta Terra. Buscando a sua felicidade exclusivamente neste mundo e violando as leis da natureza humana, tendo como mentor o próprio Diabo, o ser humano constrói para si mesmo a própria desgraça. Os judeus prometem aos povos que se encontram sob o jugo do socialismo que o Grande Líder "os governará com cetro e mão de ferro". Assim, a sociedade revolucionária será primeiramente um paraíso na terra para depois se tornar um inferno também aqui na terra.
\end{abstract}

\footnotetext{
16 “A cooperação com o Comunismo será sempre uma ameaça para a própria Igreja. O Comunismo é filho da Sinagoga e até a construção de um Estado Judaico a Sinagoga Judaica será a Sinagoga do Demônio, e o Comunismo será o Comunismo do Diabo. Será, então, o trabalho e a personificação do AntiCristo". (VOTOS e documentos preparatórios para o Concílio Vaticano II, 1961, p. 192-193).
} 
É indispensável que se ensine que as diferenças sociais e econômicas são essenciais para a vida normal da sociedade e que essas diferenças não constituem injustiça, desde que não sejam demasiadamente acentuadas na iníqua base do "poucos com quase tudo e muitos com quase nada". Para o bom andamento da sociedade, isto é, da comunidade humana, as diferenças ou classes sempre existirão, regidas, porém, pelos princípios da solidariedade, do respeito e da justiça.

O Socialismo instiga e incita o povo para o ódio às virtudes cristãs da caridade, da pobreza e da castidade. (VOTOS e documentos preparatórios para o Concílio Vaticano II, 1961, p. 192-193).

Ainda são tecidas considerações acerca da presença do Estado na vida do cidadão, cuja acentuada ingerência é, para ele, fruto da dissolução da vida coletiva, implementada pelo Liberalismo. Para Dom Sigaud, o recurso ao Estado na busca de soluções para os conflitos e problemas do mundo moderno deve ser substituído pela cristianização dos costumes:

Se Deus e Jesus Cristo forem aceitos como o fundamento da vida individual, familiar e nacional, as próprias forças da natureza farão surgir soluções naturais delas decorrentes e que deverão ser aceitas com humildade e boa disposição de ânimo como eficazes colaboradores para o bem-estar geral. (VOTOS e documentos preparatórios para o Concílio Vaticano II, 1961, p. 194).

Finaliza seu votum com um alerta ao fato de muitos sociólogos católicos estarem anunciando uma "Nova Humanidade" prestes a nascer. Rememora a concepção evolucionista para rechaçar a ideia de que, a partir da chegada ao estágio de Super Homem, outras deverão ser as leis do Direito Natural e a moral. Tudo isso requer uma reelaboração a ser apresentada e proposta aos católicos:

Se o Concílio Ecumênico propuser um programa positivo e exequível de ação contrarrevolucionária e de revigoramento da Cristandade com projetos concretos e bem definidos e para tal empreendimento convocar todos os católicos, julgo que estará raiando definitiva a aurora do Reino do Sagrado Coração de Jesus e do Imaculado Coração de Maria. (VOTOS e documentos preparatórios para o Concílio Vaticano II, 1961, p. 194-195).

A perspectiva final que apresentou fechava a questão: para o arcebispo Proença Sigaud uma cristandade devia ser implantada. 


\section{Votum de Helder Pessoa Camara}

A leitura do rápido votum de Helder Camara17 evidencia a existência de um vocábulo que se repete por três vezes: comunismo; porém, sem estar acompanhado por uma constelação de locuções e/ou expressões afins.

A primeira sugestão concreta do então Arcebispo Auxiliar da Arquidiocese do Rio de Janeiro, faz referência à língua a ser usada no Concílio:

Antes de tudo julgo conveniente sugerir um total apoio - e oxalá a citada "Comissão" [antepreparatória] assim o entenda e encampe essa ideia - que o latim não seja a única língua do Concílio. Com efeito, o uso de cada língua vernácula talvez faça surgir umas não pequenas vantagens que é encontrar o que de melhor deverá ser feito para que todos encontrem uma mesma linguagem. Uma vez que se deve levar em conta que são muito poucos, exceto a Cúria Romana e as Universidades de Roma, [os] que tenham condições de falar e de escrever com boa fluência a língua latina. Somente para dar um exemplo, apenas 5\% (cinco por cento) dos Senhores Bispos [do Brasil] aceitam e se encontram em condições de trabalhar nesse tradicional sistema. (VOTOS e documentos preparatórios para o Concílio Vaticano II, 1961, p. 325).

Discorre, na sequência, acerca da necessidade de se atentar para o fato de serem relevantes tanto assuntos para os quais convirjam muitos bispos, quanto aqueles em situação contrária, pois o segundo caso não sinaliza a ausência de buscas de fins comuns desejados por todos. Destaca, ainda, a existência de questões interdependentes requerendo as respectivas soluções.

Após tais premissas, Helder Pessoa Camara ${ }^{18}$ propõe seis temas a serem trabalhados no Concílio, a seu ver necessários para a melhoria global, a que intitula "criação de um mundo mais feliz":

1. Na Economia

Algumas atividades da Igreja na promoção dos países menos desenvolvidos.

2. Na Estética

A Igreja e as Artes do Belo em nosso tempo.

3. Na Ciência

A Igreja e a Ciência hoje e no futuro.

4. Na Política

\footnotetext{
${ }^{17}$ A disparidade já referida no número de páginas ocupadas pelos vota de Sigaud (16) e de Camara (3), implicou, neste trabalho, maiores citações e análises do votum de Dom Geraldo em relação ao de Dom Helder.

${ }^{18}$ Talvez um dos brasileiros de maior renome do século XX, foi um homem múltiplo. Sua vida tem ensejado numerosas publicações a partir de diversificados ângulos analíticos. Além de leitor voraz (adquiria e fazia minuciosas anotações nos livros), estabeleceu tão vasta rede de relações que torna difícil estabelecer, no pensamento expresso em seu reduzido votum, a direta e marcante influência de determinada(s) pessoa(s). Mais dados podem ser encontrados em PILETTI, PRAXEDES, 1997 e PINA NETA, 2018.
} 
A Igreja e o Estado.

5. Na Sociologia (nas atividades sociais)

Atividades da igreja na promoção dos operários;

A Igreja e a libertação dos povos do domínio colonialista.

6. Na Religião

Os ensinamentos do Sínodo Tridentino adaptados aos nossos dias;

O apelo pela unidade da Igreja;

Qual o posicionamento da Igreja sobre as comentadas viagens ao espaço'19. (VOTOS e documentos preparatórios para o Concílio Vaticano II, 1961, p. 325-326).

Dos pontos supraelencados, rapidamente comenta o primeiro ao chamar a atenção sobre contendas existentes entre nações poderosas e destacar ser "trágico observar que duas terças partes do gênero humano, além de viverem em constantes conflitos, sofrem de penúria extrema”. Aventa, então, a possibilidade de o Concílio "orientar e aconselhar com que atividades e com que auxílios financeiros a Igreja poderia libertar aquelas nações da influência do Comunismo". Pensando no alcance do seu desejo, recorda não ser algo difícil para a América Latina, cujo Conselho Episcopal - o CELAM $^{20}$ - tem competência para auxiliar no processo. Destaca que o objetivo seria "elevar as nações da nossa América a uma melhor condição de vida"; para tanto, propõe que se lance mão de uma composição com o[s] governo[s] no estabelecimento de uma agenda que estimule cidades e empresas mais abastadas numa dinâmica de doações na qual os bispos poderão colaborar. Tudo isso, sem perder de vista a possibilidade de estender aos continentes asiático e africano o que for feito na América Latina. Destaca, ainda, não se tratar "de como combater o Comunismo", pois "o que importa, prioritariamente, é que a Igreja 'cristianifique' essas populações, distanciadas da religião, como antigamente cristianizava povos bárbaros e pagãos”. (VOTOS e documentos preparatórios para o Concílio Vaticano II, 1961, p. 326-327).

\footnotetext{
${ }^{19}$ Embora a redação seja anterior à chegada do homem à lua, tal preocupação acompanhou Helder Camara bem após junho de 1969. Por exemplo, em carta publicada no Diário de Pernambuco (07 de maio de 2000), dirigida ao bispo casado argentino Jerónimo Podestá e sua esposa Clélia, ele comentou três sonhos seus. No terceiro, tratou do "diálogo autêntico com os mundos dos mundos". Depois de discorrer sobre a pequenez do nosso planeta, foi além: "Será orgulho absurdo pretender que a vida e sobretudo vida inteligente e livre somente exista na Terra." O destaque que damos a essa perspectiva objetiva enfatizar o nível de abertura que, evidenciado por ocasião da escrita do seu votum, esteve presente na continuidade do pensamento helderiano. Cf. ARAGÃO In: CABRAL; PINA NETA, 2018.

${ }^{20}$ Destacamos que, à época, Helder Camara era um dos vice-presidentes do CELAM. Isso implicava a possibilidade de o Conselho Episcopal Latino-americano vir a ser uma instância vital na execução das medidas que, a seu ver, decorreriam das orientações/decisões conciliares. Sabemos que os significados de Helder para o CELAM foram além do aspecto mencionado, embora não seja objetivo deste trabalho ocuparmo-nos deles.
} 
O planejamento contido nos seis temas, propostos por Helder Camara para a agenda conciliar, está claramente em sintonia com as ideias que disseminou e com o conjunto do que fez ao longo de sua vida: podemos condensá-lo na luta pela compreensão das barreiras que dividiam a humanidade e pela adoção de medidas que conduzissem às suas superações ${ }^{21}$.

Nesse mesmo diapasão, durante o Concílio Helder Camara dedicou esforços pela aprovação do chamado "Esquema XIII"22 que originou a Constituição Pastoral Gaudium et Spes - o que o coloca em sintonia com a terceira dentre as três expectativas suscitadas pelo anúncio do Concílio, elencadas por Alberigo (1995) e supracitadas - e para que fosse discutida a questão da pobreza no mundo.

Desde o final de outubro [de 1962] tinha começado a trabalhar com regularidade [...] um grupo informal de padres e peritos particularmente sensíveis aos problemas da pobreza. O grupo, embora de origens e experiências muito diferentes, reconhecia que havia uma separação entre a Igreja e os pobres - tanto nos países industrializados quanto no Terceiro Mundo - e que isso tinha origem na identificação da Igreja com a civilização capitalista. (ALBERIGO, 1995, p. 402).

Enfatizamos que o tema da pobreza era recorrente. Giuseppe Alberigo (1995, p. 405), destacou que, durante o Concílio, “o arcebispo de Bolonha, Lercaro, sublinhou a exigência da pobreza da Igreja não como condição moral, mas como sinal da encarnação num mundo que rejeita a pobreza, embora esta caracterize dois terços da humanidade”.

Inserido, entre outros grupos, no chamado "Grupo da Igreja dos Pobres", Helder Camara apoiou, na condição de um dos seus signatários, o "Pacto das Catacumbas”, assinado em Roma aos 16 de novembro de 1965². E a Arquidiocese de Olinda e Recife foi, por excelência, local para o testemunho de sua fidelidade aos itens aprovados por aquele conjunto de bispos.

\footnotetext{
${ }^{21}$ Lembramos que, no final da década de 1970, quando foi procurado por um sacerdote e maestro suíço - Pierre Kaelin - que lhe propôs a realização de uma cantata sobre ele, Helder somente aceitou depois de chegarem ao consenso de que seria uma síntese das ideias que disseminava. Surgiu, então, a "Sinfonia dos Dois Mundos", na qual é exaltada a percepção helderiana acerca da mais letal das divisões da humanidade: a estabelecida entre o hemisfério Norte, rico, e o Sul, pobre. Cf. SILVA, 2018.

${ }^{22}$ Conforme explicação dos organizadores da publicação - Zildo Rocha e Daniel Sigal -, "a Gaudium et Spes trata fundamentalmente das relações entre a Igreja Católica e o mundo onde ela está e atua. Inicialmente ela constituía o famoso 'Esquema XIII', assim chamado por ser esse o lugar que ocupava na lista dos documentos estabelecida em 1964". (CAMARA, 2013a, p. 431).

${ }^{23}$ Cf. INSTITUTO DOM HELDER CAMARA (2015).
} 
Ao término das análises acerca dos dois vota, para enfatizar, lembramos aos leitores que não há neles um sentido estático. Antes, eles são passíveis de constantes agregações de significados plurais e mutáveis, posto que representaram, sobretudo - conforme explicitado no item 1 deste artigo - o horizonte de expectativa dos bispos. Tal explicação visa a não suscitar o aguardo de uma discussão acerca da visualização inequívoca de pontos dos vota emitidos por Sigaud e por Camara nas constituições, decretos e declarações resultantes da assembleia conciliar e, menos ainda, na materialização deles ${ }^{24}$. Em linguagem mais eclesial, na aplicação e recepção das diretrizes conciliares.

Nesse panorama de espera acompanhada do desejo de realização, Helder Camara finaliza seu votum afirmando almejar, "sob a orientação da Santa Madre Igreja, dedicar-se totalmente ao trabalho de promoção e desenvolvimento da América Latina.” (VOTOS e documentos preparatórios para o Concílio Vaticano II, 1961, p. 327).

\section{Transversalidades nos dois vota}

Um primeiro aspecto se evidencia: para ambos é inestimável o papel que a Igreja tem a desenvolver no mundo - orientadora e guia dos povos. Todavia, divergem em percepções estruturais: para Proença Sigaud parece estar evidente a existência de apenas duas opções de atuação que se sintetizam nas possibilidades de adesão ao catolicismo ou ao comunismo; para Helder Camara, no entanto, o diálogo com o mundo, em suas expressões econômicas, culturais, científicas, políticas e religiosas, deve ser a razão de ser da instituição e, em consequência, impõe-se que, a partir de tal diálogo, seja pautada a agenda conciliar.

A ênfase de Proença Sigaud é na supremacia da Igreja que precisa exercer não apenas hegemonia, mas um poder coordenador que também cerceie, condene e limite múltiplos aspectos da vida das pessoas, preconizando uma "volta à rigorosa 'cristandade' e ao modelo de Igreja pós-tridentina". (BARAÚNA In: BEOZZO, 1993, p. 151). Daí as suas sugestões, entre outras, as

\footnotetext{
${ }^{24}$ Tal análise implicaria muitos desdobramentos, e eles confeririam um volume excessivo ao artigo (que já não é tão pequeno); além disso, ela não está no horizonte imediato dos objetivos a que nos propusemos.
} 
de: ampliar a lista de erros apontados no Syllabus Errorum Modernorum; louvar a eficácia da existência de um catálogo de livros proibidos que, a seu ver, devia ser atualizado²5; condenar algumas manifestações culturais expressas, por exemplo, na filosofia e em diversas modalidades das artes, como a dança, o cinema e a literatura.

O votum de Proença Sigaud olha para dentro da Igreja e a reconhece como única possibilidade de oposição à marcha da revolução que avançava, o que requeria fossem retomadas as denúncias da "metafísica da seita comunista" para a restauração da Cidade de Deus. Por duas vezes bradou: "façamos a revolução nós mesmos antes que outros o façam” (VOTOS e documentos preparatórios para o Concílio Vaticano II, 1961, p. 181), e "façamos nós, católicos, a Revolução antes que os comunistas a implantem." (VOTOS e documentos preparatórios para o Concílio Vaticano II, 1961, p. 189).

Tal finalidade restauradora exigia admoestações referentes, inclusive, a uma pauta de costumes que era, aliás, muito comum em várias práticas da Igreja durante algumas décadas do século XX. As reprimendas que Proença Sigaud apresenta em seu votum, no desejo de que o Concílio as encampasse, abrangiam um amplo leque cuja extensão começava nas vestes femininas, passava por concursos de beleza e pelas danças (a serem evitados) e chegava aos perigos representados por certos livros e pelo cinema ${ }^{26}$.

A radicalidade de Proença Sigaud é inconteste com relação ao antagonismo entre a Cidade dos Homens e a Cidade de Deus, esta a ser edificada e aquela a ser destruída. Decorre dessa separação o fato de ele ter tão categoricamente afirmado a "irreconciliável contradição entre a Igreja e o mundo". É nítida a sua perspectiva ad intra, herdeira direta da intransigência católica do século XIX.

\footnotetext{
${ }^{25}$ Sem deixar de reconhecer o papel de orientação e guia da Igreja com relação à fé e aos costumes, escreveu Helder Camara na $2{ }^{a}$ Circular Conciliar (02.10.1963): "o Index é anti-psicológico em nossos dias. Precisamos descobrir como salvar em outra Congregação, com outro nome, com outros métodos de ação o que houver de positivo na defesa da fé e dos costumes". (CAMARA, 2009a, p. 165). O Index Librorum Prohibitorum, todavia, não passou por ampliação, como desejava o Bispo de Jacarezinho, tampouco por aperfeiçoamento, como pensou o Auxiliar do Rio de Janeiro; atualizado até a sua 32a edição (de 1948), foi abolido em 15 de novembro de 1966. Cf. nota de rodapé de no 669, da 52a Circular Conciliar (24/25.10.1964), de Dom Helder. (CAMARA, 2009b, p. 203).

${ }^{26}$ Embora não caiba nas finalidades deste trabalho, é interessante destacar o quanto Dom Helder, ao longo de sua vida, guardou proximidade com as artes, sendo ele mesmo, além de incentivador delas, um artista (chegou, entre outros muitos trabalhos, a escrever argumentos para uma sinfonia e para um balé). A esse respeito ver, nas referências: CABRAL; PINA NETA, 2018.
} 
Expressando a mesma preocupação amorosa para com os rumos da Igreja, mas em perspectiva um tanto contrária, Helder Camara escreveu o seu votum. Todo ele expressa uma preocupação - até certo ponto profética - de contato e diálogo com o mundo e, outrossim, com a possibilidade de estabelecer parcerias com as demais instituições nele atuantes.

O primeiro ponto da agenda que sugeriu ao Concílio conduz àquelas que foram duas das maiores preocupações de sua atividade episcopal: as barreiras existentes entre dois mundos e a proposição das formas de ultrapassá-las. Para ele, aliás, conforme já citamos, en passant (nota de rodapé de $\mathrm{n}^{0} 21$ ), bem mais perniciosa e letal que a separação política entre leste comunista e oeste capitalista, era a acentuada diferença existente entre os hemisférios sul pobre e norte rico ${ }^{27}$. Dessa inquietação decorreu sua proposta de que o Concílio examinasse as atividades que a Igreja poderia viabilizar objetivando a promoção dos países menos desenvolvidos. Neste afã, de forma diferente da de Proença Sigaud, via as artes como aliadas poderosas, e apontou, como segundo ponto para a agenda conciliar, "a Igreja e as Artes do Belo em nosso tempo". Aqui lembramos ter o então Bispo de Jacarezinho visto problemas até na arte abstracionista, pois ela, a seu ver, é uma expressão do positivismo jurídico, do maniqueísmo e do gnosticismo, todos a serem evitados. (VOTOS e documentos preparatórios para o Concílio Vaticano II, 1961, p. 190).

Depois de ter elencado como terceiro item o diálogo entre a Igreja e a Ciência - "hoje e no futuro" - Helder Camara sugeriu como ponto de debates sobre a dimensão política, a relação entre Igreja e Estado e, em seguida, discussões sociológicas que versassem sobre a promoção dos operários e acerca do papel da Igreja na "libertação dos povos do domínio colonialista". Não é demais destacar que, ao referir-se ao comunismo, não o fez, como salientou, para combatê-lo: sua ênfase recaía sobre a cristianização das populações em tal regime, uma vez que ele implicava, conforme argumentação corrente, o

\footnotetext{
27 Documento assinado por Plínio Corrêa de Oliveira, encontrado na Cúria Arquidiocesana de Diamantina, datado em 10 de fevereiro de 1969, com o título "O arcebispo vermelho abre as portas da América Latina e do mundo para o comunismo", critica essa posição de Helder Camara - na ocasião o faz a propósito de discurso por este proferido no encerramento da Sexta Conferência Anual do programa Católico de Cooperação Interamericana (CICOP), no qual repetira sua percepção/tese. Para o Prof. Plínio Oliveira, no entanto, "essa afirmação sibilina é de molde a adormecer a vigilância dos anticomunistas, ao mesmo tempo que relega para um nível secundário a grande controvérsia religiosa, filosófica e cultural entre o mundo cristão e o mundo ateu, para pôr em primeira plana o problema econômico do subdesenvolvimento. Inversão de valores inteiramente conforme à doutrina de Marx".
} 
distanciamento da religião. Destacamos que ele não preconizava a condenação da utopia socialista; ao contrário, pensou em como ampliá-la, como veremos.

Ainda queremos destacar a existência, em ambos, de uma certa tendência de fazer previsões por demais abrangentes. Já destacamos ter Proença Sigaud afirmado, peremptoriamente, que muito em breve a Maçonaria atingiria [dominaria] toda a humanidade. Similar generalização totalizante foi elaborada por Helder Camara, posteriormente, ao escrever na $369^{\mathrm{a}}$ Circular Pós-conciliar (10/02.03.1968) - passados pouco mais de dois anos da finalização do Concílio: "eis um dado de importância decisiva para os cem anos próximos de caminhada da humanidade. O Mundo marcha para o socialismo.” (CAMARA, 2013b, p. 15). $\mathrm{Na}$ mesma carta acrescentou o quanto seria eficaz os cristãos oferecerem ao socialismo as místicas da fraternidade universal e da esperança total, em lugar da mística estreita oriunda das lutas de classes (mecanicismo histórico). Constatamos, então, o quanto ambos estiveram equivocados: a Maçonaria não atingiu e/ou dominou toda a humanidade e, tampouco, o mundo parece marchar para o socialismo. Dados geopolíticos da atualidade desaconselham a adoção dessa perspectiva, ainda que o ponto de vista helderiano tenha ainda aproximadamente meio século para vir a concretizar-se.

Neste ponto do trabalho julgamos válido o realce à coerência das posições expressas nos vota de Proença Sigaud e de Helder Camara, com a continuidade das suas trajetórias episcopais. Tal constatação motivou-nos a estabelecer conscientes do distanciamento temporal que, para nós, não configura anacronismo - a comparação sobre a qual acabamos de discorrer no parágrafo imediatamente anterior.

Finalizando seu votum, no que considerou como uma agenda "religiosa" Helder Camara sugeriu, à hodiernidade, uma adaptação dos ensinamentos do Concílio de Trento e a invocação da unidade dos cristãos (ver, acima, o que disse Proença Sigaud acerca das relações com os não católicos); terminou expressando o seu desejo de que a Igreja se pronunciasse sobre as comentadas viagens espaciais. 
Era possível uma perspectiva mais ad extra? Em sua amplitude ela contemplava, inclusive, a questão das fronteiras do espaço.

\section{Considerações finais}

Antes de tecermos comentários transversais mais conclusivos acerca dos dois epíscopos - no Concílio e fora dele -, julgamos necessário um quadro acerca de aspectos pontuais comuns à vida de ambos, na perspectiva de que, antes de serem padres conciliares, foram homens que dedicaram suas vidas ao sacerdócio e, através de tal exercício, desenvolveram atividades pastorais e sociais.

Além de lhes conferir historicidade, ao também destacar as suas atividades pastorais e sociais o quadro os sintoniza com uma das características da assembleia conciliar, da qual um dos traços característicos apontados

referia-se à "pastoralidade" do concílio, como superação da dicotomia doutrina-disciplina, favorecendo uma consideração global das exigências da Igreja no seu interior e nas suas relações com a sociedade; daí derivava uma indisponibilidade à definição de novos dogmas bem como à decretação de novas condenações. (ALBERIGO, 1995, p. 397).

O artigo já possibilitou a percepção de que, especialmente no tocante ao comunismo, por exemplo, foram díspares, nos vota dos dois padres conciliares brasileiros, a opção entre condená-lo ou não.

\section{Quadro 1 - Dados gerais}

\begin{tabular}{|c|c|c|}
\hline & GERALDO DE PROENÇA SIGAUD & HELDER PESSOA CAMARA \\
\hline \multirow[t]{2}{*}{ Data nascimento } & 26 de setembro de 1909 & O9 de fevereiro de 1909 \\
\hline & \multicolumn{2}{|c|}{ Quando D. Geraldo nasceu, D. Helder tinha 7 meses e 17 dias } \\
\hline Local nascimento & Belo Horizonte - MG & Fortaleza - CE \\
\hline Formação & $\begin{array}{l}\text { Ensino Fundamental e Médio (1919- } \\
\text { 1926) e Filosofia (1927-1928): Juiz de } \\
\text { Fora - MG (Casas de formação dos } \\
\text { Verbitas); Teologia (1928-1932): } \\
\text { Roma (Universidade Gregoriana). }\end{array}$ & $\begin{array}{l}\text { Ensino Fundamental e Médio, } \\
\text { Filo- } \\
\text { sofia e Teologia (1923-1931): } \\
\text { Forta- } \\
\text { leza (Seminário da Prainha, } \\
\text { então dirigido pelos Lazaristas). }\end{array}$ \\
\hline Ordenação & 12 de março de 1932 (aos 22 anos) & $\begin{array}{l}15 \text { de agosto de } 1931 \text { (aos } 22 \\
\text { anos) }\end{array}$ \\
\hline Exerc. sacerdócio & 67 anos e 06 meses & 68 anos \\
\hline $\begin{array}{l}\text { Sagração } \\
\text { episcopal }\end{array}$ & $1^{\circ}$ de maio de 1947 (aos 37 anos) & $\begin{array}{l}20 \text { de abril de } 1952 \text { (aos } 43 \\
\text { anos) }\end{array}$ \\
\hline & Bispo de Jacarezinho (PR) - 1947 a & $\begin{array}{l}\text { Bispo Auxiliar do Rio de Janeiro } \\
\text { - } 1952 \text { a 1955; }\end{array}$ \\
\hline
\end{tabular}




\begin{tabular}{|c|c|c|}
\hline Sedes episcopais & $\begin{array}{l}\text { 1961; } \\
\text { Arcebispo de Diamantina (MG) - } \\
1961 \text { a 1980. }\end{array}$ & $\begin{array}{l}\text { Arcebispo Auxiliar do Rio de } \\
\text { Janeiro - 1955 a 1964; } \\
\text { Arcebispo de Olinda e Recife - } \\
1964 \text { a 1985. }\end{array}$ \\
\hline Lema & $\begin{array}{l}\text { Da per Matrem (Dá por intermédio } \\
\text { da Mãe) }\end{array}$ & In manus tuas (Nas tuas mãos) \\
\hline Renúncia & $\begin{array}{l}10 \text { de setembro de } 1980 \text {, por questões } \\
\text { de saúde. }\end{array}$ & $\begin{array}{l}\text { 1984, por idade canônica. Foi } \\
\text { substituído em } 15 \text { de julho de } \\
\text { 1985. }\end{array}$ \\
\hline Exerc. episcopado & 33 anos e 04 meses & 33 anos e 03 meses \\
\hline Peculiaridades & $\begin{array}{l}\text { Profunda devoção mariana; } \\
\text { Imenso respeito pelo papado; } \\
\text { Relevantes ações sociais } \\
\text { implementadas }{ }^{28} \text {. }\end{array}$ & $\begin{array}{l}\text { Profunda devoção mariana; } \\
\text { Imenso respeito pelo papado; } \\
\text { Relevantes ações sociais } \\
\text { implementadas. }\end{array}$ \\
\hline $\begin{array}{l}\text { Atuação na Edu- } \\
\text { cação Superior }\end{array}$ & $\begin{array}{llll}\text { Professor da PUC } & \text { São Paulo, da } \\
\text { Faculdade de } & \text { Filosofia } & \text { de } \\
\text { Jacarezinho e da Universidade do } & \text { Uale do Jequitinhonha (Diamantina). }\end{array}$ & $\begin{array}{l}\text { Técnico na Secretaria de } \\
\text { Educação do DF e do Ministério } \\
\text { da Educação; Professor das } \\
\text { Faculdades Católicas e do } \\
\text { Instituto Santa Úrsula (Rio de } \\
\text { Janeiro). }\end{array}$ \\
\hline Fundações & $\begin{array}{l}\text { Ajudou a criar a primeira casa dos } \\
\text { Servos do Verbo Divino em Portugal; } \\
\text { Faculdade de Ciências e Letras de } \\
\text { Jacarezinho; } \\
\text { Ação Social Centro-Norte de Minas } \\
\text { Gerais (ASCENOMIG); } \\
\text { Artesanato Comercial de Tapetes } \\
\text { Arraiolos de Diamantina; } \\
\text { Instituto Anthropos do Brasil; } \\
\text { Congregação das Filhas de Nossa } \\
\text { Senhora de Nazaré. }\end{array}$ & $\begin{array}{l}\text { Promotor da criação da CNBB; } \\
\text { Promotor da criação do CELAM; } \\
\text { Cruzada São Sebastião (no Rio); } \\
\text { Banco da Providência (no Rio e } \\
\text { no Recife); } \\
\text { Operação Esperança (no Recife); } \\
\text { Liderou encontros de estudos a } \\
\text { partir dos quais técnicos e } \\
\text { políticos chegaram à criação da } \\
\text { SUDENE. }\end{array}$ \\
\hline $\begin{array}{l}\text { Participação } \\
\text { política 'radical } \\
\text { à direita' }\end{array}$ & $\begin{array}{l}\text { Apoiador da Sociedade Brasileira de } \\
\text { Defesa da Tradição, Família e } \\
\text { Propriedade (anos 1960). A TFP } \\
\text { afastou-se dele quando percebeu seu } \\
\text { distanciamento de princípios por ela } \\
\text { defendidos } 29 \text {. }\end{array}$ & $\begin{array}{l}\text { Membro efetivo da Ação } \\
\text { Integralista Brasileira (anos } \\
\text { 1930). Dela desligou-se pouco } \\
\text { depois de chegar ao Rio, por } \\
\text { exigência de D. Sebastião Leme. }\end{array}$ \\
\hline \multirow[t]{2}{*}{$\begin{array}{l}\text { Na Ação } \\
\text { Católica }\end{array}$} & $\begin{array}{l}\text { Assistente da Juventude Estudantil } \\
\text { Católica Masculina e da JEC } \\
\text { Feminina, em ambas de } 1938 \text { a } 1944 .\end{array}$ & $\begin{array}{l}\text { Assistente Nacional da Ação } \\
\text { Católica Brasileira (de } 1952 \text { a } \\
\text { 1962) }\end{array}$ \\
\hline & & $\begin{array}{l}\text { Esteve nos quatro períodos; } \\
\text { Encaminhou } \quad \text { intervenções } \\
\text { escritas (em seu nome e em }\end{array}$ \\
\hline
\end{tabular}

${ }^{28}$ As ações sociais implementadas por Helder Camara são bastante conhecidas, talvez em proporção direta à existência de mais obras publicadas sobre sua vida, se comparadas ao quanto já se publicou sobre Proença Sigaud. Aos interessados nas iniciativas sociais deste, notadamente em sua permanência na Arquidiocese de Diamantina, recomendamos FIGUEIREDO; FERNANDES; CONCEIÇÃO, 2010, obra citada nas referências deste artigo.

${ }^{29}$ Vasta correspondência entre Geraldo de Proença Sigaud e Antonio de Castro Mayer e Plínio Corrêa de Oliveira, encontrada no Arquivo da Cúria Arquidiocesana de Diamantina elucida a questão. Ficamos com apenas dois exemplos: primeiro, em 29 de outubro de 1969 escreveu Proença Sigaud ao Prof. Plínio, esclarecendo sua opinião acerca da Lei de Reforma Agrária, do Governo Costa e Silva - à qual se mostrara favorável - e sobre a possibilidade, por ele ventilada em reunião da CNBB, da existência de um clero auxiliar, composto por homens casados, com encargos definidos e restritos: "Creio que tanto o assunto da Reforma Agrária, como do celibato, merecia que nós conversássemos antes de eu ir à Europa. Vocês [o Prof. Plínio e Castro Mayer] não quiseram uma conversa julgando a minha posição já definitiva e irrevogável. Ela não o é. Eu fico sempre aberto a razões objetivas contrárias às minhas decisões. [...] Como bispo, não posso continuar a ouvir a vocês antes de eu falar, como se eu fosse o porta voz de um grupo de leigos. De outro lado, vocês cresceram muito, tomam decisões importantes sem me consultar e sem me ouvir. É natural. Vocês são uma sociedade civil. Meu papel é informá-los sobre a posição da Igreja, quando consultado por vocês. Suas decisões civis devem ser tomadas por vocês, sem nenhuma ingerência minha. Hoje vocês são uma organização civil mundial. É necessário que sua atuação não me envolva"; segundo, em correspondência anterior - 08 de outubro de 1969 - mesmos destinatário e remetente, encontramos sobre os assuntos que foram expostos na carta posterior supracitada: "em círculos eclesiásticos se comentou largamente que, na última reunião da CNBB Dom Sigaud "mudou", a ponto de ter recebido parabéns de Dom Helder". (Grifos nossos). 


\begin{tabular}{|c|c|c|}
\hline No Concílio & $\begin{array}{l}\text { Esteve nos quatro períodos; } \\
\text { Fez intervenções orais e encaminhou } \\
\text { escritas (em seu nome e em } \\
\text { conjunto); } \\
\text { Organizou um grupo e redes de } \\
\text { apoio; } \\
\text { Indicou Dr. Plínio Corrêa de Oliveira } \\
\text { para auditor e não logrou sucesso. }\end{array}$ & $\begin{array}{l}\text { conjunto); } \\
\text { Organizou grupos e redes de } \\
\text { apoio; } \\
\text { Teve assessores do Rio e um do } \\
\text { Recife indicados peritos, mas } \\
\text { não obteve êxito na indicação de } \\
\text { Raimundo Caramuru Barros3o; } \\
\text { Membro da Comissão } \\
\text { preparatória "Para a disciplina } \\
\text { do clero"; da Comissão ao } \\
\text { Membro da } \\
\text { "Apostolado dos Leigos e Meios } \\
\text { de Comunicação Social". }\end{array}$ \\
\hline Cartas Pastorais & Sobre a seita comunista & Não escreveu \\
\hline Publicações & Catecismo Anticomunista ${ }^{31}$ & $\begin{array}{l}\text { Inúmeras obras em português e } \\
\text { em outras línguas }{ }^{32}\end{array}$ \\
\hline $\begin{array}{l}\text { Prêmios e } \\
\text { indicações }\end{array}$ & Não houve relevantes & $\begin{array}{l}\text { Numerosos doutorados honoris } \\
\text { causa; } \\
\text { Títulos e prêmios de diferentes } \\
\text { naturezas; } \\
\text { Quatro indicações ao Nobel da } \\
\text { Paz. }\end{array}$ \\
\hline Data falecimento & $\begin{array}{l}\text { O5 setembro } 1999 \text { (21 dias antes de } \\
\text { completar 90 anos) }\end{array}$ & $\begin{array}{l}27 \text { de agosto de } 1999 \text { (com } 90 \\
\text { anos e } 06 \text { meses de idade) }\end{array}$ \\
\hline & \multicolumn{2}{|c|}{ Dom Geraldo Sigaud faleceu nove dias depois de Dom Helder Camara } \\
\hline Local falecimento & Belo Horizonte - MG & Recife - PE \\
\hline
\end{tabular}

Fonte: (BEOZZO, 2005; PILETTI; PRAXEDES, 1997; FIGUEIREDO; FERNANDES; CONCEIÇÃO, 2010) e documentos do Arquivo da Cúria Arquidiocesana de Diamantina.

Os dados sintetizados no quadro acima evidenciam o quanto transcorreram de forma paralela as vidas daqueles dois líderes eclesiais brasileiros. Nelas, há aspectos similares como cronologia (nascimento e morte), tempo de exercício de ministério sacerdotal/episcopal e formação, pois, em que pese o fato de pertencer ao clero diocesano, Helder Camara foi formado sob a direção dos padres Lazaristas e Proença Sigaud era membro da Congregação dos Missionários do Verbo Divino. Consideramos desnecessário discorrer sobre as duas famílias religiosas citadas e os papéis que elas têm desempenhado em seus específicos campos de atuação.

\footnotetext{
${ }^{30}$ O padre Raimundo Caramuru Barros não foi nomeado "oficialmente", por objeção de Dom Jaime de Barros Câmara (do Rio), que fora seu bispo e primeiro reitor de seminário na Diocese de Mossoró (RN), pois o Cardeal o considerou muito jovem e temeu que tornar-se perito do Concílio pudesse envaidecê-lo por demais. Ainda assim, trabalhou, em diferentes períodos, no/pelo Concílio tanto a partir do Rio quanto de Roma; nessa cidade, aliás, assessorou a CNBB na elaboração/ampliação do seu Plano de Emergência institucional (BEOZZO, 2005, p. 320-322).

${ }^{31}$ Embora a obra Reforma agrária - questão de consciência [RA-QC] - ver nas referências: SIGAUD; MAYER; OLIVEIRA; FREITAS, 1963) - traga o Arcebispo de Diamantina como seu primeiro autor, uma carta de Plínio Corrêa de Oliveira para Proença Sigaud, encontrada no arquivo da Cúria daquela Arquidiocese, de 11 de agosto de 1959, não deixa dúvidas de que ele não foi um dos que a escreveu: "quando o Jango estava na Presidência, o Mendonça e eu tivemos um trabalho insano para escrever a RA-QC. A CAL fez despesas enormes para divulgar o livro. Nossos militantes percorreram grande parte do País no afã de tornar conhecida a obra. $V$. Excia. e D. Mayer se expuseram a desavenças das mais desagradáveis com a CNBB, por terem aquiescido em honrar com seus nomes a obra, e lhe sustentar publicamente tanto a doutrina quanto a aplicação dela aos fatos". (Grifos nossos).

${ }^{32}$ Relações completas podem ser encontradas em obras sobre Helder Camara. O mesmo afirmamos quanto a doutorados honoris causa e títulos e prêmios. Arrolá-los foge aos objetivos deste trabalho.
} 
Simultaneamente, podemos apontar como grandes diferenciadores as sedes episcopais em que atuaram, pois são por demais eloquentes as dissemelhanças entre as cidades de Jacarezinho (PR) e Diamantina (MG), se comparadas ao tamanho - e às implicações decorrentes das complexidades sociais, políticas, culturais, econômicas e eclesiais - de cidades com o porte do Rio de Janeiro e mesmo do Recife.

Outras afinidades 33 ainda merecem destaque, uma vez que, no quadro, apontamos como características comuns uma profunda devoção mariana, o imenso respeito pelo papado e relevantes ações sociais implementadas, as três com adjetivos cuidadosamente escolhidos para antepô-las, uma vez que nosso objetivo é mais o de chamar a atenção, do que apenas suscitar estranhezas com as peculiaridades apontadas. Este aspecto ganha relevância, a fortiori, quando estamos analisando perfis antagônicos de baluartes das correntes conservadoras e progressistas católicas no Brasil - embora com ressonâncias que ecoavam além da esfera nacional - do século XX, sobretudo, mas não exclusivamente, no tocante ao que expressaram como suas perspectivas para o Concílio Vaticano II.

Não menos relevantes foram as articulações34 que ambos implementaram durante o Concílio, notadamente através do Coetus Internationalis Patrum, secretariado por Proença Sigaud, e em numerosos grupos como, por exemplo, o Opus Angeli, através dos quais Helder Camara buscava realizar o que julgava serem “missões que Deus me confia no Vaticano II", entre as quais cita, na $24^{\text {a }}$ Circular Conciliar (04/05.11.1962), “ajudar o Concílio a realizar-se segundo os planos de Deus e as necessidades da Igreja e do mundo de hoje" e "facilitar o diálogo e catolicizar a Igreja”. (CAMARA, 2009a, p. 72).

É ainda interessante enfatizar que ambos vivenciaram, em fases distintas, guinadas políticas mais à direita, através de aproximações, apoios ou militâncias junto ao Integralismo (por um período reduzido de tempo, da parte de Helder

\footnotetext{
${ }^{33}$ Lembramos aos leitores que no objetivo maior de estudar transversalidades, neste momento do artigo estamos analisando aproximações; as diferenças entre ambos ocuparam grande parte do trabalho quando nos debruçamos sobre o conteúdo dos vota dos dois personagens que, sobretudo, possuíam diferentes concepções de Igreja.

${ }^{34}$ Além de numerosas obras que discorrem sobre os grupos animados por Camara e Sigaud, remetemos eventuais interessados ao Dicionário do Concílio Vaticano II (PASSOS; SANCHEZ, 2015). As conferências realizadas na Domus Mariae (local de hospedagem da maioria dos padres conciliares do Brasil) e outras formas de articulação/disseminação de ideias utilizadas pelos dois prelados podem ser facilmente encontradas recorrendo-se ao Dicionário citado e a outras obras bastante conhecidas, das quais destacamos BEOZZO (2005). Discorrer sobre cada uma delas extrapola os objetivos deste artigo.
} 
Camara) e à TFP (com mais longa duração, no caso de Proença Sigaud). Apesar de termos feito o destaque, não nos propusemos, inclusive pelos limites e objetivos do artigo, a analisar as perspectivas, inclusive eclesiais, contidas naqueles movimentos/organizações. Em diapasão similar, ressaltamos terem os dois ocupado parte de seus ministérios como assistentes, em distintos níveis, da Ação Católica que, em grande fase de sua atuação, foi considerada pelos analistas uma organização de cunho notadamente progressista no catolicismo.

Também é até curioso realçarmos a ousadia - assim considerada por se tratar de um epíscopo incluído, segundo a tipologia elaborada por Baraúna e já citada neste trabalho, na "minoria ultrarreacionária" (1993, p. 151), e que permanece desconhecida pela quase totalidade dos estudiosos - do Arcebispo Sigaud que pensou e escreveu sobre a possibilidade da existência de um clero auxiliar, composto por homens casados, ainda que com encargos definidos e restritos (ver nota de rodapé que discorre sobre correspondências entre Proença Sigaud, Castro Mayer e Plínio Corrêa de Oliveira), o que implicaria duas categorias de clérigos e subordinação dos casados aos celibatários35.

Embora a nota suprarreferida mencione correspondência de outubro de 1969, em carta anterior, também encontrada no Arquivo da Cúria Arquidiocesana de Diamantina, de Proença Sigaud para Carlos [Eduardo de Saboia] Bandeira de Melo, então Bispo da Diocese de Palmas-Francisco Beltrão (PR), datada de 30 de setembro de 1965 (portanto, em pleno Concílio) o, à época, Arcebispo de Diamantina já falava sobre a questão, embora afirmasse não estar podendo responder a um religioso que publicara artigo sobre a sacralização do serviço pastoral, também devido ao fato de a "resposta do Santo Padre aos Bispos que queriam tratar do celibato no Concílio [...] ter representado uma refutação bastante vigorosa dessas tentativas empreendidas por Padres Jesuítas e Dominicanos”.

Os consilia et vota de Helder Camara e Proença Sigaud - analisados neste artigo sem perder de vista a perspectiva de que pensá-los implica a consciência de que eram homens inseridos em seu tempo histórico expressaram perspectivas eclesiais pontuadas por acentuadas divergências e por

\footnotetext{
${ }^{35}$ O entendimento teológico dessa proposta não faz parte dos objetivos do nosso artigo.
} 
algumas similaridades que se confirmaram nas articulações que empreenderam durante o Concílio e através dos registros escritos que deixaram acerca daquela assembleia. Ao mesmo tempo, e sem constituir um paradoxo, a análise também fez emergir a necessidade de não serem colocadas como alternativas irreconciliáveis as discussões acerca do papel das individualidades e do coletivo nos trabalhos empreendidos por historiadores, cientistas da religião etc. Complementares e imprescindíveis, os dois âmbitos devem ser considerados em suas importâncias não excludentes.

Instigante síntese sobre a atuação daqueles dois grandes bispos brasileiros no Concílio foi lavrada por um deles, o Arcebispo de Olinda e Recife que, em sua $8^{\mathrm{a}}$ Circular Conciliar (17/18.09.1965) quando, depois de tecer comentários acerca de variados aspectos do andamento do Vaticano II, escreveu: "enquanto isso, é curioso, outro brasileiro - Dom Sigaud - com certeza com a mesma sinceridade e o mesmo amor à Igreja, reúne Bispos do Mundo inteiro para combater 'as ideias progressistas'”. (CAMARA, 2009c, p. 24).

Embora ainda válidos, os conceitos de conservadorismo e progressismo, aplicados a atuações de católicos, evidenciam a necessidade de uma abrangência analítica capaz de contemplar polissemias e idiossincrasias. Assim, os embates entre conservadorismo e progressismo católicos, neste artigo analisados com o foco primordial nas perspectivas conciliares, respectivamente dos arcebispos Geraldo de Proença Sigaud (Diamantina) e Helder Pessoa Camara (Olinda e Recife), requerem, como condição sine qua non para uma compreensão mais ampla, a adoção da perspectiva de que foram homens cuja ação esteve balizada pela honestidade para com os seus princípios pessoais ${ }^{36}$, a partir da condição institucional de bispos de uma mesma Igreja na qual militaram imbuídos de similar perspectiva de doação integral à instituição a que consagraram suas vidas, antes, durante e depois do Concílio Ecumênico do Vaticano II.

\footnotetext{
${ }^{36}$ Embora a honestidade faça parte da fecundidade da vida cristã - e, como tal, possa parecer descabido destacá-la na vida de dois arcebispos - alguns críticos destacam, a partir do lugar hierárquico ocupado, a possibilidade de se enunciar não o que se pensa, mas, sim, o que é requerido pela instituição. Como exemplo, sugerimos artigo publicado por Rubem Alves, citado nas referências.
} 


\section{REFERÊNCIAS}

ALBERIGO, Giuseppe (org.). História dos concílios ecumênicos. São Paulo: Paulus, 1995 .

ALVES, Rubem. Quem não pode transar não pode casar. Folha de São Paulo, São Paulo, Tendências/Debates, 05 mai 1996.

ARAGÃO, Gilbraz de Souza. "O Artista tem medida especial para os artistas”. In: CABRAL, Newton Darwin de Andrade Cabral; PINA NETA, Lucy. "Andar às voltas com o belo é andar às voltas com Deus": a relação de Dom Helder Camara com as artes. Recife: Bagaço, 2018. p. 9-22.

BARAÚNA, Luiz J. Brasil. In: BEOZZO, José Oscar (org.). A Igreja latinoamericana às vésperas do Concílio Ecumênico Vaticano II. São Paulo: Paulinas, 1993.

BEOZZO, José Oscar. A Igreja do Brasil no Concílio Vaticano II: 1959-1965. São Paulo: Paulinas, 2005.

CABRAL, Newton Darwin de Andrade; PINA NETA, Lucy (org.). "Andar às voltas com o belo é andar às voltas com Deus": a relação de Dom Helder Camara com as artes. Recife: Bagaço, 2018.

CALDEIRA, Rodrigo Coppe. Os baluartes da tradição: o conservadorismo católico brasileiro no Concílio Vaticano II. Curitiba: CRV, 2011.

CAMARA, Dom Helder. Circulares conciliares: de 10/11 de setembro a 7/8 de dezembro de 1965. Recife: CEPE, 2009[c]. (Obras Completas de Dom Helder. V. 1, T. 3). Org.: Luiz Carlos Luz Marques e Roberto de Araújo Faria.

CAMARA, Dom Helder. Circulares conciliares: de 12 de setembro a 22/23 de novembro de 1964. Recife: CEPE, 2009[b]. (Obras Completas de Dom Helder. V. 1, T. 2). Org.: Luiz Carlos Luz Marques e Roberto de Araújo Faria.

CAMARA, Dom Helder. Circulares conciliares: de 13/14 de outubro de 1962 a [14 de] março de 1964. Recife: CEPE, 2009[a]. (Obras Completas de Dom Helder. V. 1, T. 1). Org.: Luiz Carlos Luz Marques e Roberto de Araújo Faria.

CAMARA, Dom Helder. Circulares pós-conciliares: de 31 de dezembro de 1966/10 de janeiro de 1967 a 29/30 de julho de 1967. Recife: CEPE, 2013a. (Obras Completas de Dom Helder. V. 3, T. 3). Org.: Zildo Rocha e Daniel Sigal.

CAMARA, Dom Helder. Circulares pós-conciliares: de 5/6 de agosto de 1967 a 13/14 de fevereiro de 1968. Recife: CEPE, 2013b. (Obras Completas de Dom Helder. V. 4, T. 1). Org.: Zildo Rocha e Daniel Sigal.

FIGUEIREDO, Anísia de Paulo; FERNANDES, Antônio Carlos; CONCEIÇÃO, Wander José da (org.). A terra, o pão, a justiça social: a importante participação da Igreja nas políticas públicas no Brasil. Belo Horizonte: Editora FUMARC, 2010. 
INSTITUTO DOM HELDER CAMARA. O pacto: ideário de uma igreja pobre e servidora. Recife: CEDOHC, 2015.

KOSELLECK, Reinhart. Futuro passado: contribuição à semântica dos tempos históricos. Rio de Janeiro: Contraponto; PUC Rio, 2006.

MAINWARING, Scott. Igreja católica e política no Brasil. São Paulo: Brasiliense, 1989.

PASSOS, João Décio; SANCHEZ, Wagner Lopes (coord.). Dicionário do Concílio Vaticano II. São Paulo: Paulinas; Paulus, 2015.

PILETTI, Nélson; PRAXEDES, Walter. Dom Hélder Câmara: entre o poder e a profecia. São Paulo: Ática, 1997.

PINA NETA, Lucy. O dom da leitura: Helder Camara e suas bibliotecas. São Paulo: Paulinas, 2018.

REIS, José Carlos. Tempo, história e evasão. Campinas: Papirus, 1994.

SIGAUD, Dom Geraldo de Proença. Carta pastoral sobre a seita comunista: seus erros, sua ação revolucionária e os deveres dos católicos na hora presente. 2. ed. São Paulo: Editora Vera Cruz, 1963.

SIGAUD, Dom Geraldo de Proença. Catecismo anticomunista. Belo Horizonte: Edições Cristo Rei, 2018.

SIGAUD, Dom Geraldo de Proença; MAYER, Dom Antonio de Castro; OLIVEIRA, Plínio Corrêa de; FREITAS, Luiz Mendonça. Reforma agrária: questão de consciência. 4. ed. São Paulo: Editora Vera Cruz, 1962.

SILVA, Cícero Williams da. Dom Helder Camara e a Sinfonia dos Dois Mundos. Recife: Bagaço, 2018.

VOTOS e documentos preparatórios para o Concílio Vaticano II. In: Acta et documenta concilio oecumenico Vaticano II: consilia et vota episcoporum ac praelatorum. v. II, pars VII, 1961. p. 180-195; 325-327. (Trad. José Gaudêncio de Oliveira Lopes). Fundo Vaticano de São Paulo, Biblioteca da Ordem Social Redentorista. 